\title{
REMOVAL OF ORGANIC LOAD IN COMMUNAL WASTEWATER BY USING THE SIX STAGE ANAEROBIC BAFFLE REACTOR (ABR)
}

\author{
Minarni Nur Trilita, Novirina Hendrasarie and Iwan Wahjudijanto \\ University of Pembangunan National "Veteran" Jawa Timur, Surabaya, East Java, Indonesia \\ E-Mail: trilita69@yahoo.com
}

\begin{abstract}
The reduction of water quality in the urban drainage is a crucial problem to overcome because it can affect the health of community. This fact encouraged the researcher to conduct the research in efforts to increase the water quality in the drainage. One of the solutions to increase the water quality in the drainage is that the domestic wastewater must be treated at first before it is flown through the drainage. Furthermore, the wastewater treatment was conducted by employing the communal wastewater processor. The research was aimed at knowing the capability of Anaerobic Baffle Reactor with the six-stage design in communal wastewater processor in efforts to decrease the organic load. This research was conducted in a laboratory scale. Meanwhile, the sort of waste used was taken from the domestic wastewater of settlement by varying its discharge and waste concentration flowing into the waste processor. Finally, the research result showed that the reduction of organic load of COD was reaching up to $92 \%$, $\mathrm{N}$ was $85 \%$ and Phosphate was $50 \%$.
\end{abstract}

Keywords: suspended microbiology, anaerobic process, domestic wastewater

\section{INTRODUCTION}

In developing countries, especially in the urban areas, the reduction of water quality in the drainage is often found. This reduction of water quality in the drainage might cause some nuisance to the community's health. Therefore, the increase of water quality in the drainage is required. One of the solutions is by making use of communal wastewater processor to make the wastewater flowing in the drainage already fulfill the water quality permitted in efforts to increase the self purification of environment.

The process commonly used in Indonesia to treat the domestic waste water is septic tank which combines anaerobic and infiltration. Septic tank is a simple process and quite cheap, and it is only appropriate for the less crowded population. If implemented in the urban areas with crowded population, it might cause some contamination of the water under the ground. However, septic tank usually treats the wastewater from the lavatory only. Meanwhile, the other wastewater such as the laundry wash, kitchen and bath room, they are usually directly thrown out without being treated. This might cause some contamination in that area. Furthermore, the Centralized Sewage Treatment System requires much money. (Benefield and Randall, 1980; Grady and Lim, 1980; Metcalf and Eddy. 2003). Therefore, the process communal wastewater treatment is an important and realistic option in efforts to treat the domestic wastewater around the river bank, so that the disposal will not contaminate or pollute the self purification of the river.

Anaerobic Baffle Reactor (ABR) is anaerobic suspended treatment system in a baffle reactor. Meanwhile, the suspended growth is more advantageous than the attached growth because it does not need supporting media and is not easily plugged up. ABR is an Upflow anaerobic Sludge Blanket (UASB) installed in series, but it does not need any particle in its operation, so that the shorter start-up period is required. Furthermore, a series of vertical partition is put in the $A B R$ to make the wastewater flow under and over from inlet to outlet, so that there will be a contact between wastewater and active biomass. The concentration profile of organic compounds varies along the ABR. This might cause the population growth of microorganism different between that of put in one compartment and another. This depended on the condition of specific environment produced by the compound as a result of decomposition (Malakahmad et.al., 2011, Wang et.al., 2004, Shanmugam and Akunna, 2010; Liu et.al., 2007; Kuşcu and Teresa, 2007; Jamshidi and Khalesidoost, 2014; Young and Young, 1988; Grobicki, Aand Stuckey, D.C., 1992).

The bacteria in the bioreactor will float or settle in accordance with the characteristics of flow and gas produced. However, it can move horizontally to the top of reactor slowly so that it can increase its cell retention time. Furthermore, while the contacted wastewater with active biomass was flowing, the effluent was free from biological solids. This configuration could show the high rate of COD elimination (Sinan Uyanik, 2003; Wang, Jianlong, et.al., 2004).

Furthermore, communal wastewater system design is used in this research. To make the performance of ABR more efficient, pre-treatment is added. The pre-treatment used in this research includes equalizing tank and primary clarifier. The 
function of equalizing tank is to make the stream's flow of the wastewater to be treated become stable its fluctuation. Meanwhile, primary clarifier is used to reduce the solid matter to be removed in the wastewater gravitationally so that the $\mathrm{ABR}$ reactor does not work harder.

Some advantages of ABR are its capability of separating the asidogenesis process and metanogenesis longitudinally that enables its reactor have two-phase system. This means that this phase does not need any control and does not spend much money. Its design is also quite simple, it does not need mechanical mixer, it spends less money for its construction cost. Besides, its biomass does not need a specific characteristics of sedimentation, it contains low sludge, and its hydraulic system of ABR is capable of reducing the bacteria from losing.

Considering with the low cost and it is easy to be implemented in a urban community especially in developing countries, biological communal wastewater processor of anaerobic baffle reactor was chosen in this research. Meanwhile, the anaerobic baffle reactor with the six-stage design was expected to be capable of reducing the total of nitrate and phosphate load in the domestic wastewater. Therefore, this research was aimed at knowing the capability of communal wastewater processor in efforts to reduce/decrease the organic load in the domestic wastewater.

\section{METHODOLOGY}

The research was conducted by designing Anaerobic Baffle Reactor (ABR) with 6 stages applied in the communal wastewater. The tool design of the experiment was based on the calculation. Meanwhile, the reactor of $A B R$ was made of fiber plastic (Figure 1).

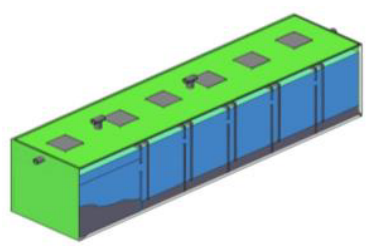

Figure-1 Schematic Anaerobic Baffle Reactor in Table 1.

The more specific about it was explained

Table-1. Specifications of Reactor

\begin{tabular}{|l|l|}
\hline \multicolumn{1}{|c|}{ Description } & ABR \\
\hline The width of Settling Tank $(\mathrm{m})$ & 0.33 \\
\hline Depth $(\mathrm{m})$ & 0.43 \\
\hline Up flow velocity (m/hour) & 1.8 \\
\hline The number of chamber & 5 \\
\hline Depth of outlet (m) & 0.75 \\
\hline L : D & $0.5: 0.75$ \\
\hline
\end{tabular}

Based on the research scheme, it could be explained in Figure 2.

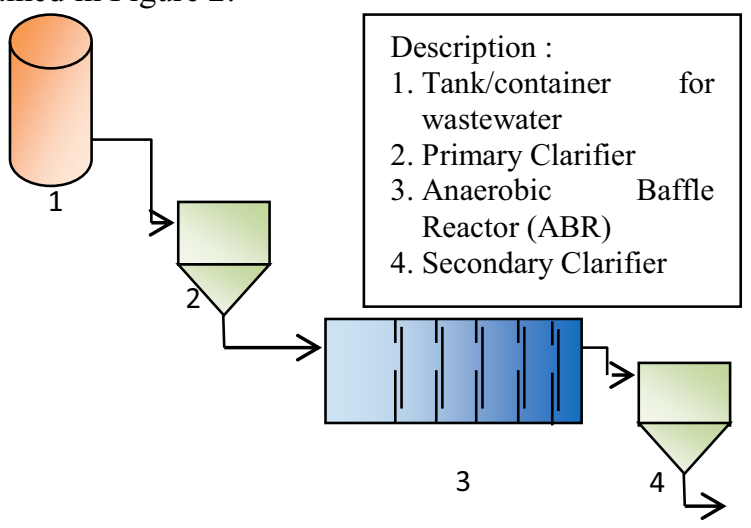

Figure-2. Schematic Experimental Set Up

The wastewater used in this research was communal wastewater with the former characteristic of wastewater of COD $=150-800$ $\mathrm{mg} / \mathrm{L}, \mathrm{BOD} 5=75-400 \mathrm{mg} / \mathrm{L}, \mathrm{TSS}=134-786$ $\mathrm{mg} / \mathrm{L}, \mathrm{pH}= \pm 7 \mathrm{~N}$ Total $=250-700 \mathrm{mg} \mathrm{N} / \mathrm{L}$, PO4 $=20-60 \mathrm{mg} / \mathrm{L}$. The bacteria to be breed was taken from its own communal wastewater. This was done by varying the inflow discharge as the following: $120 \mathrm{~mL} /$ minute, $140 \mathrm{~mL} /$ minute, $160 \mathrm{~mL} /$ minute, $180 \mathrm{~mL} / \mathrm{minute}$, and $200 \mathrm{~mL} / \mathrm{mnt}$. Based on this experiment, it could be obtained that HRT was about $16.47-27.45$ hours.

\section{RESULTS AND DISCUSSIONS}

The capability of eliminating the organic substance of the communal wastewater employing ABR could be seen from the following discussion

\section{Seeding Stage and Acclimatization}

There were 4 (four) stages in the metabolism of bacteria growth: hydrolysis, asidogenes, asethogenesis, and methanogenesis. These four stages of anaerobic processes must be conducted in efforts to make the reactor of ABR be ready to use. Furthermore, these four stages were conducted during seeding process, so that it would be obtained the appropriate bacteria. At first, when the seeding process happened, there was $\mathrm{pH}$ decrease (hydrolysis, asidogenesis and asethogenesis) and it will become stable if the range of $\mathrm{pH}$ is $6.6-7.6$ (methanogenesis stage). However, during the seeding process, some nutrient was required for microorganism growth or bacteria with its comparison as $\mathrm{C}: \mathrm{N}: \mathrm{P}=100: 5$ : 1 , added with some glucose as a source of $\mathrm{C}$, Urea (fertilizer) as a source of $\mathrm{N}$, and $\mathrm{Kh} 2 \mathrm{PO} 4$ as a source of $\mathrm{P}$. The initial result of analysis was known that $\mathrm{COD}=560.64 \mathrm{mg} / \mathrm{L}$, total $\mathrm{N}=493.3$ $\mathrm{mg} / \mathrm{l}$ and Phosphate $=24.51 \mathrm{mg} / \mathrm{l}$. Based on this result (nutrient comparison), there should have been some more glucose addition and phosphate, 
so that the score for COD would become COD = $6451.2064 \mathrm{mg} / \mathrm{l}$.

Furthermore, aclimatization process was conducted in efforts to adapt the bacteria available in ABR with the wastewater to be treated. Aclimatization was conducted with the wastewater concentration of $50 \%$ up to $100 \%$. Aclimatization was stopped when the outlet of ABR got its score < $50 \%$ from the initial wastewater. To reduce the COD content about $50 \%-75 \%$, it was required 1 day and 2 days for the concentration of $100 \%$ with the percentage of COD decrease as much as $81 \%$. This indicated that the reactor was ready to use and operate.

\section{The removal of Organic Substance of Communal Wastewater}

The analysis result of organic substance of communal wastewater that had been treated in ABR showed that the best elimination percentage of input COD concentration was $184.52 \mathrm{mg} / \mathrm{l}$, with the discharge of $140 \mathrm{ml} / \mathrm{mnt}$, HRT $=18.86$ hours in ABR. This score had already fulfilled in accordance with the established regulation/rule. The regulation employed was the Governor's Decree East Java, No 72 in the year 2013 about the standard of wastewater containing the maximum effluent of COD of $50 \mathrm{mg} / \mathrm{l}, \mathrm{TSS}=50 \mathrm{mg} / \mathrm{l}$, and $\mathrm{pH}$ $=6-9$.

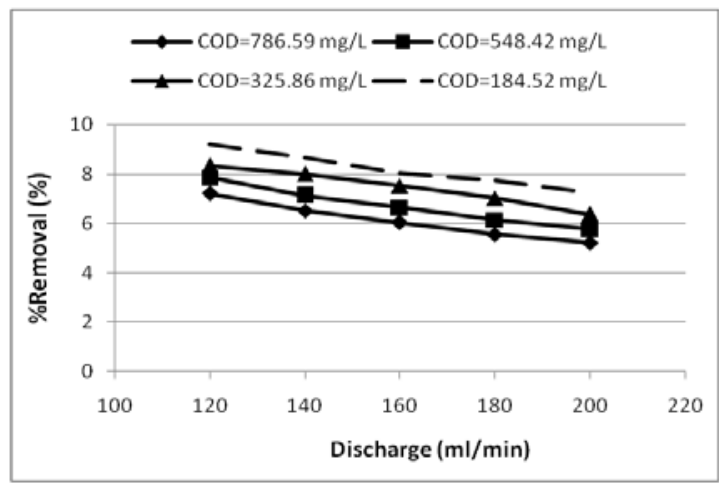

Figure-3a. Percentage of removal COD in the Primary Clarifier

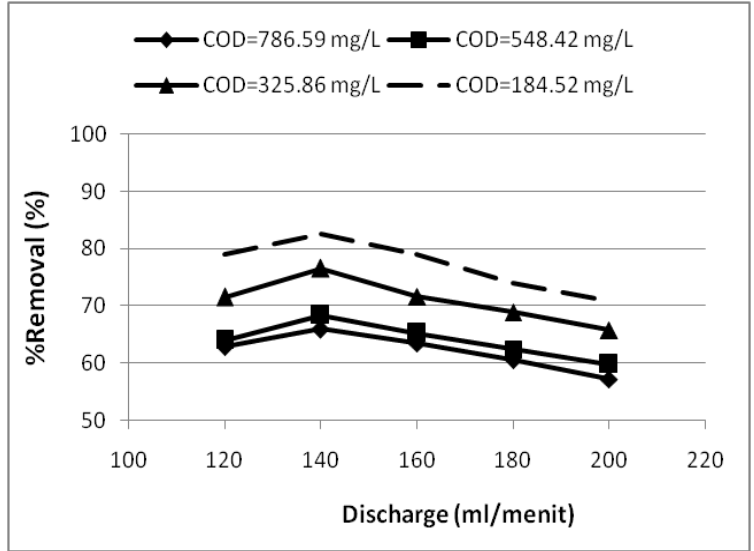

Figure-3b. Percentage of removal COD in the ABR
Based on the experimental result, the best discharge where ABR was set up, the primary clarifier was put before ABR and the secondary clarifier was put after ABR. This composition resulted in the highest elimination percentage of COD at the discharge of $140 \mathrm{ml} /$ minute with its total of HRT $=23.53$ hours. Figure 3 showed the elimination percentage of COD of each reactor.

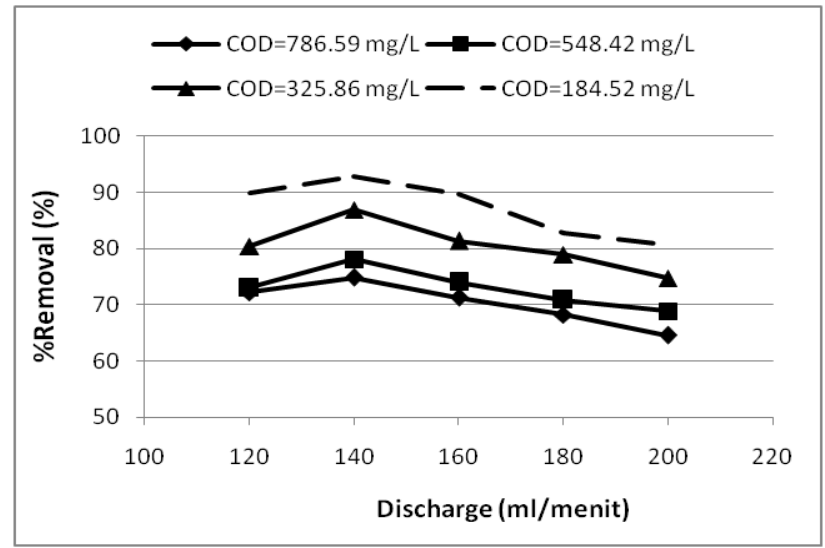

Figure-3c. Percentage of removal COD in the Secondary Clarifier

To reduce the content of Total Suspended Solid (TSS), the best score was obtained from secondary clarifier with its concentration variation of $\mathrm{COD}=134.52 \mathrm{mg} / \mathrm{l}$ with its discharge $=140$ $\mathrm{ml} / \mathrm{minute}$ (HRT 18.86 hours), elimination percentage $=95.67 \%$. Meanwhile, the concentration score of initial TSS of $1010 \mathrm{mg} / \mathrm{l}$, the score of final TSS was $44 \mathrm{mg} / \mathrm{l}$. This score had already fulfilled the standard established, that was less than $50 \mathrm{mg} / \mathrm{l}$ (Figure 4).

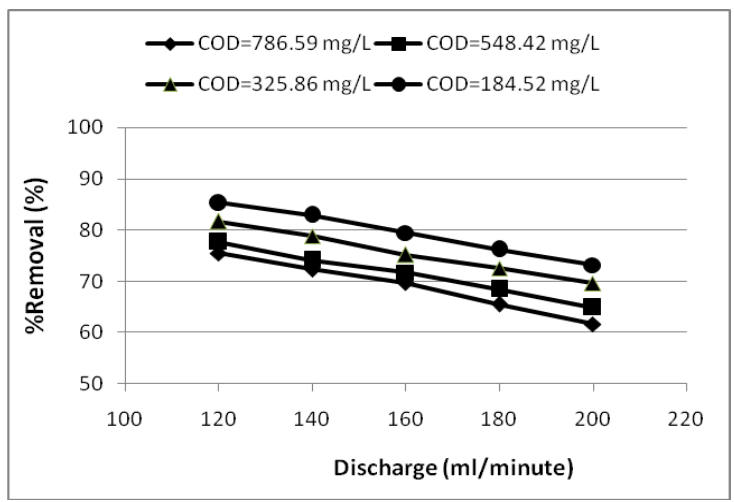

Figure-4. Percentage of removal N-Total in the Outlet $\mathrm{ABR}$

Meanwhile, to reduce the total content of Nitrogen, the best score was obtained at the discharge of $120 \mathrm{ml} /$ hour as much as $85 \%$. The reduction percentage of $\mathrm{N}$-Total was almost the same as the reduction percentage of COD and TSS which reached up to $70-80 \%$. Furthermore, the best reduction percentage of Phosphate at the discharge of $120 \mathrm{ml} /$ hour as much as $50.54 \%$. However, the reduction percentage of Phosphate was only 
reaching up to $50 \%$. This score was smaller than the reduction percentage of COD and TSS which was reaching up to $70-80 \%$ (Figure 5).

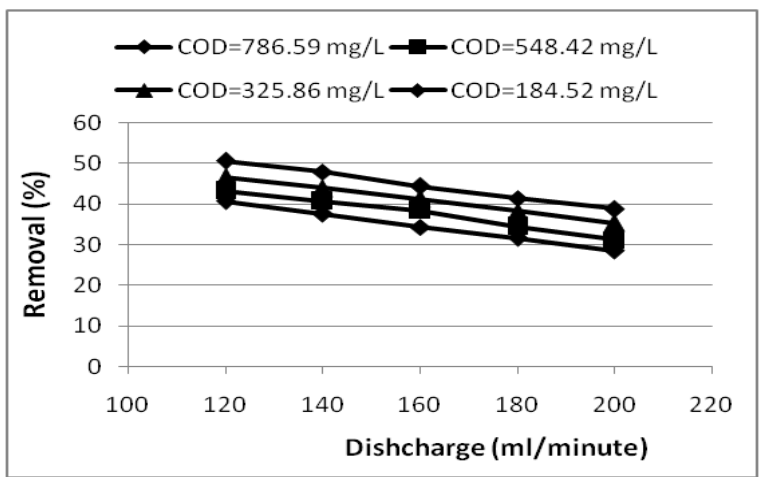

Figure-5. Percentage of removal Phosphat in the Outlet $\mathrm{ABR}$

\section{CONCLUSION}

Based on the research, it was found that the Anaerobic Baffle Reactor was capable of reducing the organic parameter of communal wastewater. This might not make the water quality flowing in the drainage be polluted. The reduction capability of organic load of domestic wastewater for COD was about $90 \%$, Total of Nitrogen was $80 \%$ and Phosphate was $50 \%$. This showed that the pretreatment design (equalizing tank \& primary clarifier) and Anaerobic Baffle Reactor (ABR) could be used in communal treatment system.

\section{ACKNOWLEDGMENTS}

This work was supported by research grants (PUPT) from DIKTI (Department of Higher Education Indonesia) in the year 2015 - 2016.

\section{REFERENCES}

Malakahmad A, et.al, 2011, Study on Performance of a Modified Anaerobic Baffled Reactor to Treat High Strengh Wastewater, Journal of Applied Sciences, Vol. 11, Issue 8. 1449-1452.

Benefield and Randall. 1980. Biological Process Design for Wastewater Treatment.

Grady, L..C.P., and Lim, C.H., 1980, Biological Wastewater Treatment, Pollution Engineering and Technology, New York.
Grobicki, A., and Stuckey, D.C., 1992, Hydrodynamic Characteristics of The Anaerobic Baffled Reactor, Water Research, Vol. 26. Issue 3, 371-378.

Jamshidi, S., Khalesidoost, M., 2014, Biogas Production Yield of Anaerobic Baffled Reactor in Low pH and HRT, Journal of Middle East Applied Science and Technology (JMEAST), Vol. 15, No. 4, pp. 765-770.

Kuşcu, Ö.S., Teresa, D., 2007, Effects of Nitrobenzene Concentrations and Hydraulic Retention Time on The Treatment of Nitrobenzene in sequential Anaerobic Baffled Reactor and Continuously Stirred Tank Reactor System, Water Science \& Technology, Vol. 55, No. 10, pp. 227 236, IWA Publishing.

Liu, Xiao-lei, Ren, Nan-qi, Wan, Chun-li, 2007, Hydrodynamic Characteristics of a Fourcompartment Periodic Anaerobic Baffed Reactor, Journal of Environmental Science (Elsevier), Vol. 19, Issue 10, p1159-1165, 7p.

Metcalf and Eddy. 2003. Waste Water Engineering Fourth Edition. NewYork: Mc .Graw-Hill Company.

Shanmugam, A.S, Akunna, J.C. 2010. Modelling Head Losses in Granular Bed Anaerobic Baffled Reactors at High Flows During Start-up, Water Research, Vol. 44 Issue 18, p5474-5480, 7p.

Uyanik S., 2003, A Novel Anaerobic Reactor: Split Fed Anaerobic Baffled Reactor (SFABR), Turkish J. Eng. Env. Sci., Vol. 27, 339-345, EBSCO Publ.

Young, H.W, and Young, James C., 1988, Hydraulics Characteristics of Upflow Anaerobic Filters, Journal Environmental Engineering, Vol. 114, No. 3, 621-638.

Wang, Jianlong, Huang, Yongheng, Zhao, Xuan, 2004, Performance and characteristic of an Anaerobic, Journal Bioresources Technology, Vol. 93, Issue 2, p205, 4p. 